\title{
Banking Crises and the Role of Bank Coalitions*
}

\author{
Daniel Sanches ${ }^{\dagger}$ \\ Federal Reserve Bank of Philadelphia ${ }^{\ddagger}$
}

November 27, 2013

\begin{abstract}
I study the effectiveness of bank coalition formation in response to an external aggregate shock that may cause disruption to the payment mechanism and trading activity. I show that a specific type of bank coalition (a joint-liability arrangement) is an effective arrangement that allows member banks to build a capital buffer that permits them to absorb the effects of an external shock. In particular, it allows society to completely prevent any disruption to trading activity that can be caused by a temporary drop in the aggregate value of banking assets, at least in the case of a shock that is not too big. If the shock is relatively large, then a bank coalition will be unable to completely prevent a disruption in trading activity even though it will be able to substantially mitigate the effects of the shock. Thus, the existence of a private bank coalition of the kind considered in this paper can be an effective means of preventing significant contractions in trading activity.
\end{abstract}

Keywords: bank coalition, banking crisis, payment system

JEL classifications: E42, G01, G21

\footnotetext{
${ }^{*}$ The author thanks Mitchell Berlin, Douglas Gale, Chao Gu, Todd Keister, Will Roberds, and David Skeie for excellent discussions. I also thank seminar participants at Wharton, New York University, Rutgers University, and the Bank of Canada.

${ }^{\dagger}$ Federal Reserve Bank of Philadelphia, Research Department, Ten Independence Mall, Philadelphia, PA 19106-1574. E-mail address: Daniel.Sanches@phil.frb.org.

$\ddagger$ The views expressed in this paper are those of the author and do not necessarily reflect those of the Federal Reserve Bank of Philadelphia or the Federal Reserve System.
} 


\section{INTRODUCTION}

The growth of the U.S. banking sector observed during the period known as the national banking era (from 1863 to 1914) was extraordinary. Together with the expansion of the banking system, many forms of banking associations developed during this period of diffusion of banking services. One particular form of bank coalition that developed in the second half of the 19th century was the clearinghouse association. The initial purpose of this form of cooperation among banks was to facilitate the clearing and settlement of interbank payments. Subsequently, it evolved into an organizational form that promoted a very integrated approach to banking activities. As opposed to markets, this form of bank coalition involved the monitoring and supervision of the activities of member banks. See Gorton (1984, 1985), Gorton and Mullineaux (1987), and Moen and Tallman (1992, 2000).

The emergence of clearinghouse associations in several cities in the U.S. suggests that, in the absence of a government agency such as a central bank, local bankers found it beneficial to form a bank coalition to economize on reserves and to effectively allocate resources among member banks. Clearinghouse associations offered an effective means of implementing interbank arrangements that were extremely valuable to local banks that faced legal restrictions on the establishment of interstate branches. Although many subsequent researchers have recognized the role of clearinghouse associations in providing monitoring and supervision services, a major concern of many contemporary economists was whether the clearinghouse associations could provide an effective means of preventing significant disruptions to real economic activity caused by sufficiently large shocks to the value of banking assets. The panic of 1907 is considered an event that decidedly changed the contemporary discussion of monetary reform, heavily influencing the subsequent design and passage of the Federal Reserve Act (see Friedman and Schwartz, 1963). Thus, the passage of this act can be interpreted as a manifestation of the belief that private clearinghouse associations were not an effective mechanism to deal with banking crises.

This distinct episode in the history of money and banking in the U.S. raises some important questions. Although these events happened over 100 years ago, their relevance for the 
current debate on the role of government regulation of the banking sector is strikingly surprising. In particular, the unintended effects of government intervention on the incentives of private banking firms to hold reserves and other liquid assets have been widely discussed in policy circles. In this discussion, a primary concern is whether a stable banking system (i.e., one in which widespread bank failures and losses to bank liability holders do not occur frequently) would arise in the absence of government regulation. Most important, economists would like to know under what conditions the goal of stability can be achieved if the provision of regulation and supervision services is left to private agents. Specifically, economists would like to know whether, in the absence of government intervention, the private banking system is willing to hold enough liquid assets (or reserves) to effectively respond to external aggregate shocks that may cause disruption to banking activities. In other words, is it possible to ensure the ex post transfer of resources from liquid banks to illiquid banks under any circumstance? These questions are of first order of importance for academics and policymakers alike.

The purpose of this paper is to characterize the properties of a specific form of bank coalition: a joint-liability arrangement. By this I mean an arrangement in which each member bank agrees to issue liabilities, referred to as bank notes, that are joint obligations of all members. Each banker continues to issue notes that identify him as a debtor, but the members of the coalition publicly announce that any note issued by a banker who is a member will be honored, according to the joint capacity of all members. First, I show that this kind of bank association is an effective arrangement to provide monitoring and supervision services to ensure the solvency of each member bank. Most important, under this arrangement, it is possible to effectively perform the transfer of reserves from liquid member banks to illiquid member banks in such a way that the overall level of required reserves is minimized.

Then, I show that a joint-liability arrangement is able to provide an effective response to an external aggregate shock that can potentially cause disruption to the payment mechanism (a shock that affects the aggregate value of banking assets) provided that such a shock is not too big. The kind of risk-sharing arrangement provided by a joint-liability arrangement 
is of particular value to banks that have limited opportunities to expand and diversify their balance sheets (historically relevant in the U.S. owing to restrictions on the establishment of branches). In particular, I show that a joint-liability arrangement is able to preserve the safety of bank liabilities as a means of payment and, consequently, ensure the smooth functioning of the payment system in the absence of government intervention.

In my formal analysis, I construct a random-matching model in which privately issued liabilities circulate as a means of payment. People meet in pairs and use bank notes to trade. The redemption of bank notes happens periodically in a centralized location where merchants who have previously sold goods to consumers take their notes to claim their face value. The key incentive problem within the banking sector arises due to hidden action: It is necessary to provide bankers with incentives to induce them to voluntarily report the creation of bank liabilities and hold the appropriate level of reserves. To deal with this incentive problem, there exists a clearinghouse association (a recordkeeping and safekeeping device) that requires member banks to report their transactions, imposes reserve requirements on each one of them, and supervises the settlement process at each date. Most important, each banker is willing to voluntarily participate in this private bank association because he or she will be better off by doing so. Thus, the kind of monitoring provided by the clearinghouse association allows each member bank to issue liabilities that effectively circulate as a means of payment.

My main result is to show that, in the case of an external shock to the value of banking assets that is not too big, a bank coalition of this kind is able to completely prevent any disruption to trading activity, i.e., there is no loss of output due to the use of bank liabilities in transactions, despite the expected drop in the aggregate value of banking assets. In particular, I show that a bank coalition is an effective arrangement for managing bank reserves that allows member banks to build a capital buffer to absorb the effects of external shocks. Thus, the members of the bank coalition are willing to absorb the losses in order to preserve the safety of bank liabilities as a means of payment.

If the drop in the aggregate value of banking assets is sufficiently large so that the joint action of all members of the clearinghouse is insufficient to fulfill the promise of redeeming 
all bank liabilities at par value, then the clearinghouse association will not be able to prevent a contraction in trading activity caused by a disruption in the payment mechanism even though it will be able to significantly reduce the effects on equilibrium quantities and prices. In particular, I show that a fully anticipated partial suspension of convertibility happens to preserve bank capital. Because traders contemplate the possibility of losses on their note holdings (and this affects contemporaneous trading activity), I refer to this event as a banking crisis. Even though no bank will actually fail as a result of a partial suspension, note holders will suffer ex post losses in case the adverse state of nature is realized.

\section{RELATED LITERATURE}

Battacharya and Gale (1987) build on Diamond and Dybvig (1983) to provide an analysis of interbank arrangements in the presence of a liquidity shock that is imperfectly correlated across intermediaries, which creates a motive for considering interbank arrangements to provide insurance for bank depositors. In my framework, I emphasize the role of bank liabilities as a means of payment and characterize the properties of a banking arrangement that can preserve the safety of these privately issued payment instruments in the presence of an aggregate shock. ${ }^{1}$

Even though the topic of bank coalition formation has been extensively discussed in the banking literature, only a few papers have tried to provide a rigorous theoretical framework for analyzing the properties of this kind of arrangement. One such paper is by McAndrews and Roberds (1995). These authors build on Diamond and Dybvig (1983) also to construct a model in which bank reserves play a role in preventing banking panics. In their model, reserves are useful to facilitate the clearing and settlement of interbank payments. Similarly, my analysis also emphasizes the role of reserves in the settlement process, perhaps in a more explicit way. In addition, I provide an analysis of the impact of external shocks to the banking system on trading activity due to the use of bank liabilities in transactions.

\footnotetext{
${ }^{1}$ See also Allen, Carletti, and Gale (forthcoming) for an analysis of insurance provision in the presence of an aggregate shock when a central bank issues fiat money to accommodate the liquidity demands of the private sector.
} 
Smith and Weber (1999) provide a formal theoretical analysis of another type of banking arrangement: the Suffolk banking system that prevailed in New England from 1836 to 1858. Many economic historians have described the Suffolk banking system as fundamentally different from clearinghouse associations even though both systems were initially designed to provide an efficient mechanism for the clearing and settlement of interbank payments. See, for instance, Gorton $(1984,1985)$ and Rolnick, Smith, and Weber (2000). In particular, an important difference referred precisely to the way in which each system responded to aggregate shocks that disrupted banking operations everywhere.

Another prominent paper that studies the properties of bank coalitions is that of Leitner (2005). This author shows that liquid banks have an incentive to bail out illiquid banks in case these institutions possess financial linkages. In his analysis, the main reason for engaging in some form of joint-liability arrangement is the threat of contagion. In my analysis, I show that banks have an incentive to engage in a joint-liability arrangement ex ante in order to insure against real aggregate shocks in the absence of any form of predetermined financial linkages. I also show that agents outside the banking sector are strictly better off in the presence of a joint-liability arrangement.

Gorton and Huang (2006) also provide a formal theoretical analysis of bank coalitions. In contrast to their analysis, I focus on the role of bank liabilities in the payment system and on the stability of such a system in the presence of an aggregate shock to the value of banking assets.

My paper also belongs to the vast literature on inside money. Some important papers in this literature include, among many others, Cavalcanti, Erosa, and Temzelides (1999); Cavalcanti and Wallace (1999); Kahn and Roberds (1999); Williamson (1999); Azariadis, Bullard, and Smith (2001); Li (2001, 2006); Martin and Schreft (2006); Berentsen (2006); Mills (2007); He, Huang, and Wright (2008); Skeie (2008); Andolfatto and Nosal (2009); Huangfu and Sun (2011); Araujo and Minetti (2011); and Gu, Mattesini, Monnet, and Wright (forthcoming). However, in these papers, the properties of bank coalitions are not the focus of the analysis. 


\section{MODEL}

Time $t=0,1,2, \ldots$ is discrete, and the horizon is infinite. Each period is divided into three subperiods or stages. There are two physical commodities, referred to as good $x$ and good $y$, that are perfectly divisible. There are three types of agents, referred to as consumers, merchants, and bankers, who are infinitely lived, with a $[0,1]$ continuum of each type.

Merchants and bankers want to consume good $x$, whereas consumers want to consume good $y$. If good $x$ is not properly stored in the subperiod it is produced, it will depreciate completely. Good $y$ is perishable and cannot be stored, so it must be consumed in the subperiod it is produced. Each consumer is able to produce good $x$ only in the first subperiod. Each merchant is able to produce good $y$ only in the second subperiod. A banker is unable to produce either good but has access to the technology to perfectly store good $x$. Also, each banker has access to a technology that allows him to create, at zero cost, an indivisible and durable object, referred to as a note, that perfectly identifies him. This means that notes issued by him are perfectly distinguishable from those issued by other bankers so that counterfeiting will not be a problem.

I now explicitly describe preferences. Let $x_{t} \in\{0,1\}$ denote a consumer's production of good $x$ at date $t$, and let $y_{t} \in \mathbb{R}_{+}$denote his consumption of good $y$ at date $t$. A consumer's preferences are represented by

$$
u\left(y_{t}\right)-\gamma x_{t}
$$

where $\gamma \in \mathbb{R}_{+}$and $u: \mathbb{R}_{+} \rightarrow \mathbb{R}$ is continuously differentiable, increasing, and strictly concave, with $u(0)=0$ and $u^{\prime}(0)=\infty$. I assume the production technology of good $x$ allows a consumer to produce either zero or one unit of good $x$ at each date even though good $x$ is perfectly divisible.

Let $y_{t} \in \mathbb{R}_{+}$denote a merchant's production of good $y$ at date $t$, and let $x_{t} \in \mathbb{R}_{+}$denote his consumption of good $x$ at date $t$. A merchant's preferences are represented by

$$
v\left(x_{t}\right)-\omega y_{t},
$$

where $\omega \in \mathbb{R}_{+}$and $v: \mathbb{R}_{+} \rightarrow \mathbb{R}$ is continuously differentiable, increasing, and concave, with 
$v(0)=0$. The merchant's technology to produce good $y$ is perfectly divisible.

Each banker derives utility $x_{t}$ if his or her consumption of good $x$ at date $t$ is $x_{t} \in \mathbb{R}_{+}$. Finally, let $\beta \in(0,1)$ denote the discount factor of each type of agent.

In each subperiod, there is a distinct round of interactions. In the first subperiod, each consumer is randomly matched with a banker. In the second subperiod, each consumer is randomly matched with a merchant with probability $\lambda \in(0,1)$. These bilateral meetings are privately observable, i.e., only the pair of agents participating in the meeting knows the amounts traded. In the third subperiod, all merchants and all bankers meet in a centralized location. I assume that, after meeting with consumers bilaterally in the first subperiod, all bankers immediately move to the centralized location. Sellers arrive at the centralized location only in the third subperiod. See Figure 1 for a sequence of events within each period.

\section{EQUILIBRIUM ALLOCATIONS WITH PERFECT PUBLIC INFORMATION}

To describe the exchange process in this economy, it is useful to start with the second stage. In this stage, each consumer is randomly matched with a merchant with probability $\lambda$. Because the consumer wants good $y$ but is unable to produce good $x$ for the merchant at that time (and is unable to store good $x$ ), the pair will be able to trade only if a medium of exchange is made available. As will become clear, each banker will be able to provide such a medium of exchange in the form of personal notes convertible into a specified amount of good $x$ on demand. Thus, the objects that a consumer and a merchant trade are good $y$ and privately issued notes.

Each consumer will be able to acquire a note in the first stage, when each one of them is randomly matched with a banker. In this stage, each consumer has access to the technology to produce good $x$, so the objects a consumer and a banker trade are good $x$ and notes. A banker who issues a note to a consumer receives one unit of good $x$ in exchange and is supposed to set aside the face value of the note (expressed in terms of good $x$ ) to retire 
such a note in case it is presented for redemption in the centralized location (an event that happens with positive probability). In the third stage, all merchants arrive at the centralized location so that all bankers and all merchants meet in this location. ${ }^{2}$ In this stage, each merchant has an opportunity to redeem any note (i.e., converting a privately issued liability into good $x$ ) he has received from a consumer (if any) in the previous stage, so we can think of the third stage as the settlement stage. Thus, two objects can be traded: good $x$ and notes. Note that no production takes place during the settlement stage. See Figure 2 for a representation of the payment mechanism.

This payment arrangement works perfectly well provided that each banker is willing to set aside (i.e., invest in the storage technology) the appropriate amount of good $x$ to have enough resources, referred to as reserves, to retire a note in case it is presented for redemption in the settlement stage. In this section, I maintain the assumption that each banker's decision to hold reserves is perfectly observable by other agents in the economy. In the following section, I relax this assumption and discuss the implications for the functioning of the payment system.

The merchant's decision to accept a note issued by a banker as a means of payment is a key element of my analysis. Under the assumption that each banker's decision to hold reserves is publicly observable, each merchant will accept a note issued by a banker with probability one provided that the banker has set aside the full face value of the note. This means that the merchant knows that the banker will be able to retire such a note at par value in the settlement stage.

Given this acceptance rule adopted by each merchant, each banker will hold the full face value of each note issued because, with some probability, a note holder will claim the face value of such a note in the settlement stage. I will also make the additional assumption

\footnotetext{
${ }^{2} \mathrm{~A}$ key assumption for tractability in my framework is that the clearing and settlement of privately issued liabilities occur in a centralized location, as in Koeppl, Monnet, and Temzelides (2008) and Deviatov and Wallace (2009). This assumption allows me to fully characterize the effects of an external aggregate shock on equilibrium prices and quantities and, consequently, focus on the welfare properties of bank coalitions, the main topic of my paper.
} 
that each banker does not opportunistically access any amount of good $x$ that he has accumulated over time to secure outstanding notes (i.e., notes have been issued but have not been redeemed). In the following section, I will also relax this assumption.

This means that, in this section, I consider the case of 100 percent reserve requirements to ensure the solvency of each individual banker in the absence of any interbank arrangement. I will show later that this requirement implies that the banking system as a whole holds excess reserves (i.e., units of good $x$ that are produced and not consumed), which is clearly inefficient. Then, I will consider an alternative institutional arrangement that will allow me to eliminate excess reserves without compromising the stability of the banking system (i.e., the fact that there will be no bank failure in equilibrium).

Finally, I assume that each agent can carry at most one indivisible unit of money at any moment. This means that individual note holdings are restricted to the set $\{0,1\}$. In this respect, the model developed in this paper relates to the second generation of searchtheoretic models of monetary exchange, following the ideas of Shi (1995) and Trejos and Wright (1995). On the other hand, there is no restriction on the number of notes that each banker is allowed to issue at any moment except for that imposed by the matching technology and people's willingness to trade. This means that the number of notes issued by any banker belongs to the set $\{0,1,2, \ldots\}$.

\subsection{Equilibrium}

Throughout the paper, I restrict attention to equilibria for which there exist an invariant distribution of note holdings across consumers, an invariant distribution of note holdings across merchants, and an invariant volume of note creation and note redemption by all members of the banking sector. These distributions can be summarized as follows. Let $m^{1} \in[0,1]$ denote the invariant measure of consumers holding one note after trading in the first stage, let $m^{2} \in[0,1]$ denote the invariant measure of merchants holding one note after trading in the second stage, and let $m^{3} \in[0,1]$ denote the invariant volume of notes that are retired in the third stage at each date. I only consider equilibria for which $m^{1}=1$ 
and $m^{2}=m^{3}=\lambda$. Thus, if each banker is willing to hold reserves to redeem his notes on demand, there will be no uncertainty with respect to the total volume of redemptions in the settlement stage. I also restrict attention to symmetric equilibria in which the notes issued by any pair of bankers will be treated equally across different matches.

One key feature of the model rendering it highly tractable is that one does not need to keep track of each banker's individual history of note creation and note redemption. Given the acceptance rule adopted by each merchant, each banker who has issued a note to a consumer will be willing to set aside the full face value of such a note so that it is fully secured by a safe asset (storage). Thus, all that matters for the characterization of an equilibrium allocation is the aggregate amount of privately issued notes in circulation outside the banking sector.

Let me start by describing the Bellman equations for each consumer. Let $V^{0}$ denote the beginning-of-period expected discounted utility of a consumer without a note, and let $V^{1}$ denote the beginning-of-period expected discounted utility of a consumer holding a note. The Bellman equations for each consumer are given by

$$
\begin{gathered}
V^{0}=-\gamma+\alpha \lambda\left[u(y)+\beta V^{0}\right]+(1-\alpha \lambda) \beta V^{1}, \\
V^{1}=\alpha \lambda\left[u(y)+\beta V^{0}\right]+(1-\alpha \lambda) \beta V^{1} .
\end{gathered}
$$

Here $y \in \mathbb{R}_{+}$denotes the amount of good $y$ that the consumer will be able to purchase from the merchant with whom he is matched in exchange for a note, and $\alpha \in[0,1]$ denotes the probability that the merchant will accept a privately issued note in exchange for his output.

If the consumer starts the period without a note, then he will be able to obtain one from the banker with whom he is currently matched, in which case he will produce one unit of good $x$. A newly issued note costs one unit of good $x$ and is a promise to pay $\phi \in[0,1]$ unit of good $x$ on demand to the note holder. Then, with probability $\lambda$, the consumer will be matched with a merchant in the second stage, in which case the consumer will be able to consume $y \in \mathbb{R}_{+}$units of good $y$ with probability $\alpha$ (and will enter the following period without a note). With probability $1-\alpha \lambda$, the consumer will not trade in the second stage and will hold on to his note. 
Note that each consumer is able to save in the form of liabilities issued by bankers (a store of value) until he has an opportunity to consume by trading with a merchant. Because each consumer is able to hold at most one note, he will not be willing to produce good $x$ again until he has an opportunity to spend his current note. This means that the consumer's wealth is completely determined by the equilibrium value of bank notes.

Let $W^{0}$ denote the expected discounted utility of a merchant who does not find a trading partner in the second stage, and let $W^{1}$ denote the expected discounted utility of a merchant who finds a trading partner. In a stationary equilibrium, the Bellman equations for a merchant are given by

$$
\begin{gathered}
W^{0}=\beta\left[\lambda W^{1}+(1-\lambda) W^{0}\right], \\
W^{1}=\max _{\alpha \in[0,1]} \alpha[-\omega y+v(\phi)]+\beta\left[\lambda W^{1}+(1-\lambda) W^{0}\right] .
\end{gathered}
$$

Under the assumption that each banker's reserve position is publicly observable (and that each banker cannot opportunistically access accumulated reserves), the banker is willing to deposit the face value of each note issued so that by accepting a banker's note in trade a merchant receives $\phi$ for sure. In the next section, I carefully discuss the incentive problem in case the creation of a bank note is privately observable and people do not observe whether a banker has set aside the appropriate amount of reserves to secure each bank note issued.

Now consider the Bellman equations for each banker. Let $J^{0}$ denote the expected discounted utility of a banker who is currently matched with a consumer not holding a note in the first stage, and let $J^{1}$ denote the expected discounted utility of a banker who is currently matched with a consumer holding a note. In a stationary equilibrium, the Bellman equations for each banker are given by

$$
\begin{gathered}
J^{0}=1-\phi+\beta\left[\alpha \lambda J^{0}+(1-\alpha \lambda) J^{1}\right] \\
J^{1}=\beta\left[\alpha \lambda J^{0}+(1-\alpha \lambda) J^{1}\right] .
\end{gathered}
$$

A banker who has issued a note is able to immediately consume the amount $1-\phi$ of good $x$. The consumption decision is trivial: The banker will save exactly the required amount. 
A banker who meets a consumer holding a note can offer his own note in exchange for the consumer's note. In this case, the banker can claim the face value of someone else's note. Because he issues his own note to purchase someone else's note, he is supposed to set aside the face value of his note. Thus, such a trade will bring no extra benefit to the banker unless the face value of the note he issues is lower. But, in this case, the consumer will clearly be better off by holding on to his (previously acquired) note. Thus, a swap of notes happens if and only if both agents are indifferent. Without loss of generality, I assume that both choose not to swap notes. ${ }^{3}$

Each merchant's decision to accept privately issued notes is trivial under the assumption that note creation by each banker and individual reserve positions are publicly observable. Each merchant is willing to accept a banker's note with probability one provided that he or she has observed that the issuer has set aside the full face value of the note when it was issued. Thus, $\alpha=1$ is individually rational for each merchant since a bank note is a truly safe payment instrument.

Let me now characterize the participation constraints in the first and second stages. Starting with the second stage, I assume that the consumer makes a take-it-or-leave-it offer to the merchant. The consumer's surplus from trade is given by

$$
u(y)+\beta V^{0}-\beta V^{1}=u(y)-\beta \gamma
$$

and the merchant's surplus from trade is given by

$$
-\omega y+v(\phi) .
$$

The consumer is willing to make any offer $y$ such that

$$
u(y)-\beta \gamma \geq 0
$$

and the merchant accepts the consumer's offer if and only if

$$
-\omega y+v(\phi) \geq 0
$$

\footnotetext{
${ }^{3}$ Even if they swapped notes, the total volume of reserves would remain unchanged because the redemption of a note by another banker simply means a transfer of reserves within the banking system, which would not affect the total stock of notes available to the nonbank public.
} 
This participation constraint will always bind because I have assumed that the consumer has all the bargaining power, so the quantity of good $y$ produced in each meeting will be given by

$$
y=\omega^{-1} v(\phi)
$$

Consider now the feasible terms of trade in the first stage. In a trade meeting, the consumer's participation constraint is given by

$$
-\gamma+\lambda u\left(\omega^{-1} v(\phi)\right)+\beta(1-\lambda)\left(V^{1}-V^{0}\right) \geq 0 .
$$

Using (1) and (2), I can rewrite this participation constraint as

$$
u\left(\omega^{-1} v(\phi)\right) \geq \frac{\gamma[1-\beta(1-\lambda)]}{\lambda}
$$

The banker's participation constraint is given by

$$
J^{0} \geq \beta\left[\lambda J^{0}+(1-\lambda) J^{1}\right]
$$

which simply requires

$$
\phi \leq 1
$$

Thus, I conclude that an equilibrium value $\phi$ must satisfy both (8) and (9). In this case, bilateral trades are completely voluntary.

The participation constraints (8) and (9) impose both a minimum and a maximum exchange value of privately issued notes consistent with equilibrium:

$$
\chi \equiv v^{-1}\left(\omega u^{-1}\left(\frac{\gamma[1-\beta(1-\lambda)]}{\lambda}\right)\right) \leq \phi \leq 1 .
$$

The minimum value arises owing to the consumer's participation constraint, whereas the maximum value arises because of the banker's participation constraint. Finally, suppose that each consumer starts date zero without a note so that each banker has an opportunity to issue a note to the consumer with whom he is initially matched. Given these requirements, it is now straightforward to formally define a stationary equilibrium. 
Definition 1 A stationary monetary equilibrium for the economy described above is an array $\left\{J^{0}, J^{1}, V^{0}, V^{1}, W^{0}, W^{1}, \phi, y, \alpha, m^{1}, m^{2}, m^{3}\right\}$ satisfying $m^{1}=1, m^{2}=m^{3}=\lambda, \alpha=1$, (1), (2), (3), (4), (5), (6), (7), and (10).

In this definition, I have allowed for any arbitrary rule to determine the terms of trade in the first stage. For instance, if I choose a trading protocol that assumes the banker has all bargaining power, then $\phi=\chi$. Alternatively, if I select a trading protocol that assumes the consumer has all bargaining power, then $\phi=1$.

The evolution of the volume of reserves is as follows. At date zero, each banker issues a note to the consumer with whom he is initially matched so that the total volume of reserves after the first round of trades is given by $\phi$ (in terms of good $x$ ). In the settlement stage, a fraction $\lambda$ of outstanding notes is retired, so the total volume of reserves decreases by $\lambda \phi$. Thus, the excess reserves at the end of date zero are given by $(1-\lambda) \phi$. After date zero, only a fraction $\lambda$ of bankers is able to issue a note in the first stage, so the total volume of reserves increases by the amount $\lambda \phi$. In the settlement stage, a fraction $\lambda$ of outstanding notes is retired, so the total volume of reserves decreases by $\lambda \phi$. This means that, in a stationary equilibrium, the total volume of reserves at the end of the period is exactly the same as the volume at the beginning of the period.

\subsection{Existence}

To determine the existence of a stationary equilibrium, I make the following assumption throughout the paper.

Assumption 1 Assume $\chi<1$.

Under this assumption, I can formally characterize the set of allocations that can be supported as an equilibrium outcome when each banker's decision to hold reserves is publicly observable.

Proposition 2 Any value $\phi$ in the interval given by

$$
\chi \leq \phi \leq 1
$$


can be supported as an equilibrium value of notes in a stationary monetary equilibrium. In this equilibrium, the end-of-period excess reserves are $(1-\lambda) \phi$ at each date.

Proof. Assumption 1 ensures that it is possible to simultaneously satisfy the consumer's and banker's participation constraints because consumers (and possibly merchants) are sufficiently productive. Thus, any value $\phi$ in the interval $[\chi, 1]$ satisfies all participation constraints.

To show that the end-of-period excess reserves are given by $(1-\lambda) \phi$, note that all merchants who have acquired a note are able to convert it into $\phi$ unit of good $x$ in the settlement stage. Note also that there is no reason for them to delay the redemption of a note. Because $m^{1}=1$ in a stationary equilibrium and note holdings are constrained to the set $\{0,1\}$, the total volume of reserves at the end of the first stage must be given by $\phi$. Because $m^{2}=\lambda$, the total volume of reserves decreases by the amount $\lambda \phi$ in the settlement stage. This means that the end-of-period volume of excess reserves is given by $(1-\lambda) \phi$.

The description of an equilibrium allocation is as follows. In a stationary equilibrium, each banker consumes $1-\phi$ unit of good $x$ when he has an opportunity to issue a note, each consumer gets $\omega^{-1} v(\phi)$ units of good $y$ when he has an opportunity to trade with a merchant and produces one unit of good $x$ when he acquires a note, and each merchant produces $\omega^{-1} v(\phi)$ units of good $y$ and consumes $\phi$ unit of good $x$ when he has an opportunity to trade with a consumer.

\section{EQUILIBRIUM ALLOCATIONS WITH IMPERFECT PUBLIC INFORMATION}

The trading arrangement described in the previous section works perfectly well provided each banker is willing to set aside the appropriate amount of good $x$ to have enough reserves to retire a note if it is presented for redemption in the settlement stage. Under the assumption of perfect public information regarding the creation of bank notes, it is possible to condition each merchant's acceptance rule on the banker's decision to hold reserves so that bankers are willing to set aside the full face value of each note issued. In this section, 
I will assume that neither the creation of a bank note nor the decision to hold reserves is publicly observable.

In addition, I will drop the assumption that each banker cannot opportunistically access previously accumulated reserves. This means that the possibility that a banker may have many notes outstanding following a history of successful trading meetings and few redemptions also creates a problem. In particular, a banker who has issued notes that remain in circulation (those issued to consumers who have not had an opportunity to trade with a merchant) and who has held reserves to secure these notes may want to opportunistically consume these reserves in case they become very large. The short-term payoff of defection for the banker will be enormous in some cases, making him more likely to renege on his promises.

In view of these difficulties, I explain how each banker will be able to issue private liabilities that circulate as a medium of exchange in the case of imperfect public information. There exists a clearinghouse association designed to coordinate the clearing of privately issued liabilities. Specifically, it will work as a safekeeping and recordkeeping institution that will accept deposits from bankers (who will become members) and retire notes issued by its members. Each banker can be a member of the clearinghouse at no cost but must follow its rules. The clearinghouse requires each banker to report any meeting in the first stage in which a note has been issued, as a way to track individual issuance of notes. For each note issued, the banker is required to store a fraction of the face value of the note (in terms of good $x$ ), to be interpreted as reserves backing the issuance of his note. In particular, each banker is required to "deposit" reserves with the clearinghouse association every time he announces the creation of a bank note so that he cannot opportunistically access his reserves in future periods.

Recall that I have assumed that, shortly after meeting with consumers bilaterally in the first subperiod, all bankers meet in the centralized location so that they have an opportunity to report the creation of bank notes and deposit the appropriate amount of reserves with the clearinghouse. Note that merchants arrive at the centralized location only in the third subperiod so that they do not observe the amounts deposited by each banker. See Figure 3 
for a representation of the payment mechanism with imperfect public information.

Any banker who fails to report the issuance of a note will have his membership permanently revoked. Note that his deviation will be publicly observable to the members of the clearinghouse only when an unreported note is presented for redemption in the settlement stage, which may take several periods to happen.

It is important to emphasize that the acceptability of privately issued notes is endogenously determined. A merchant's decision to accept a note issued by a banker in exchange for his output ( $\operatorname{good} y$ ) is based on the available information he has about the issuer. In this section, the available information for each merchant is provided by the clearinghouse. In particular, the clearinghouse provides a record of compliance with the clearinghouse rules for each member bank, i.e., people observe the membership status of each banker. Each merchant knows that the clearinghouse requires member banks to deposit reserves to secure bank notes and expels members that issue notes without depositing the appropriate amount of reserves (when the deviation is detected). Thus, the decision to become a member of the clearinghouse is viewed as a signal of "financial rectitude" which will certainly influence a merchant's decision to accept the notes issued by a member of the clearinghouse.

\subsection{Equilibrium}

In this section, I characterize stationary equilibrium allocations under a trading arrangement that ensures the safety of bank liabilities as a means of payment so that neither bank failures nor losses to note holders occur in equilibrium. This means that the clearinghouse will set reserve requirements in such a way that no banker fails to fulfill his promise of paying the full face value of a note on demand. As I will show, each member bank has an incentive to issue notes without depositing the appropriate amount of reserves (i.e., overissue of bank notes). Thus, the clearinghouse has to account for the possibility of individual deviations when setting reserve requirements. In the absence of any form of interbank arrangement, the only way to ensure the solvency of each individual member is to require that each banker deposit the full face value of a note when such a note is issued. 
The Bellman equations for consumers continue to be given by (1) and (2), the Bellman equations for merchants continue to be given by (3) and (4), and the Bellman equations for bankers continue to be given by (5) and (6). Under the clearinghouse association, it is also true that the expected discounted utility of each banker does not depend on his history of note creation and note redemption. On the equilibrium path, each banker is willing to deposit with the clearinghouse the amount $\phi \in[0,1]$ for each note issued so that he can immediately consume $1-\phi$ every time he issues a note. Because the clearinghouse has chosen appropriate reserve requirements to ensure the solvency of each individual member in this case, the number of notes outstanding for each banker will not influence his probability of failure. In particular, the probability of failure will be zero in equilibrium because the clearinghouse either requires each member to deposit the full face value of each note or ensures the ex post transfer of reserves from liquid banks to illiquid banks (see next section).

As in the previous section, a banker who meets a consumer holding a note can offer his own note in exchange for the consumer's note. The banker can claim the face value of someone else's note only if he reports the acquisition of such a note to the clearinghouse, in which case the clearinghouse will require him to hold reserves due to the creation of his own note. Thus, such a trade will bring no extra benefit to the banker unless the face value of his note is lower. But, in this case, the consumer will clearly be better off holding on to his (previously acquired) note. Thus, a swap of notes happens if and only if both agents are indifferent. Similarly, I assume that both choose not to swap notes.

In the absence of perfect public information regarding the creation of bank notes, each banker has the option of not reporting his newly issued note to the clearinghouse. The punishment for failing to report any newly issued note (and setting aside the required amount of reserves) is the immediate termination of his membership when his deviation is detected. A banker who has his membership revoked will not be able to issue notes that are accepted as a means of payment because merchants will choose not to accept a note issued by a banker who is not a member. Recall that consumers and merchants only observe each banker's membership status and nothing else. Thus, a merchant will choose an acceptance rule according to which he or she accepts a note issued by a member and does not accept a 
note issued by a nonmember. Finally, I will show that it may take some time between the moment a banker deviates and the moment his deviation is detected.

Each banker is willing to truthfully report the creation of a new note in the first stage if and only if

$$
1-\phi+\beta\left[\lambda J^{0}+(1-\lambda) J^{1}\right] \geq J^{d}
$$

where $J^{d}$ denotes the (stationary) value associated with his best deviation. The left-hand side gives the banker's expected discounted utility in case he chooses to truthfully report the creation of a note. The right-hand side gives the banker's expected discounted utility in case he adopts his best deviation. This means that each banker is willing to deposit with the clearinghouse the full face value of each note he has issued provided that the equilibrium value of bank notes is such that his expected discounted utility is at least the same as that which he would obtain by adopting his best deviation strategy. His best deviation strategy may involve issuing some notes without holding the appropriate amount of reserves (thereby raising his individual probability of failure) so that he may engage in fractional reserve banking.

Now I show that the value associated with a deviation strategy is bounded below by 1 and is bounded above by $(1-\beta+\lambda \beta)^{-1}\left[1-(1-\lambda)^{2} \beta\right]$. To verify that $J^{d} \geq 1$, notice that a banker who decides to deviate at any given date is able to immediately consume one unit of good $x$. His decision to not deposit reserves with the clearinghouse will certainly affect his continuation value. But, in any case, his continuation value is at least zero. Thus, I have shown that $J^{d} \geq 1$. To show that $J^{d}$ has an upper bound, consider the hypothetical case in which a banker who has deviated at some date $t$ is able to deviate at each subsequent date without increasing his probability of failure (for instance, because each note holder will freely dispose of his notes). In this case, the maximum expected discounted utility he can obtain is given by

$$
\bar{J}=1+\beta(1-\lambda) J^{\prime},
$$

where the value $J^{\prime}$ satisfies

$$
J^{\prime}=\lambda+(1-\lambda) \beta J^{\prime} .
$$


When he initially deviates at some date $t$, he is able to immediately consume one unit of good $x$. He will be able to continue trading only with probability $1-\lambda$, which is precisely the probability that the consumer who has acquired his note does not find a trading partner in the second stage. If his deviation is not detected at date $t$, he will be able to issue a new note at date $t+1$ with probability $\lambda$. After date $t$, his probability of failure will not increase (despite the fact that more than one note has been issued without the corresponding amount of reserves) because I have assumed that whoever acquires his notes after date $t$ will freely dispose of them so that his probability of survival continues to be given by $1-\lambda$ at the end of each date. It is straightforward to show that

$$
\bar{J}=\frac{1-(1-\lambda)^{2} \beta}{1-(1-\lambda) \beta} .
$$

Thus, the value associated with his best deviation $J^{d}$ is indeed bounded:

$$
1 \leq J^{d} \leq \frac{1-(1-\lambda)^{2} \beta}{1-(1-\lambda) \beta}
$$

As I have previously mentioned, a banker's best deviation strategy may involve issuing some notes without holding the appropriate amount of reserves, which will raise his individual probability of failure. To see this point, consider a deviation strategy (not necessarily his best deviation) in which a banker decides to issue notes without holding reserves. If he chooses not to report a newly issued note, he can immediately consume the amount of good $x$ he has received in exchange for his note. With probability $1-\lambda$, his deviation will remain undetected, in which case he will be able to issue a new note in the following period with probability $\lambda$. With probability $(1-\lambda)^{2}$, his deviation will remain undetected in the following period (now two of his notes are in circulation), in which case he will be able to issue a third note in the subsequent period with probability $\lambda$. Note that his probability of failure increases over time as new notes are put into circulation. As long as his deviation remains undetected, he will be able to continue to issue notes without reporting their existence to the clearinghouse, immediately consuming the proceeds from the sale of these notes. The expected discounted utility associated with this deviation strategy is given by

$$
\hat{J}=1+(1-\lambda) \beta \hat{J}_{1}
$$


where, for each $i=1,2,3, \ldots$, we have

$$
\hat{J}_{i}=\lambda\left[1+(1-\lambda)^{i+1} \beta \hat{J}_{i+1}\right]+(1-\lambda)(1-\lambda)^{i} \beta \hat{J}_{i}
$$

This strategy is likely to be his best deviation strategy in case $\lambda$ is relatively low, which means that his defection will be detected only with a small probability.

Even though a banker's best deviation strategy may not be unique, there exists a unique stationary value $J^{d}$ in the interval given by (12) that corresponds to the maximum value associated with a best deviation strategy. Finally, note that the value $J^{d}$ depends on the amount of reserves that each banker is supposed to deposit with the clearinghouse.

To guarantee that each banker voluntarily participates in the clearinghouse, it is necessary to make membership sufficiently profitable such that his expected discounted utility is at least as large as that associated with his best deviation. The truth-telling constraint (11) ensures that each individual banker holds enough reserves (deposited with the clearinghouse) to pay the full face value of each outstanding note so that it ensures the safety of bank notes as a means of payment. Thus, it is individually rational for each merchant to choose $\alpha=1$ (i.e., to accept privately issued notes with probability one) provided that (11) is satisfied. Recall that the merchant observes the face value $\phi$ associated with a note and a banker's membership status. When the value $\phi$ is such that (11) is satisfied, each merchant knows that the members of the clearinghouse are willing to deposit the required amount of reserves for each note issued. Thus, he is willing to accept a note issued by a member bank with probability one.

As in the previous section, the participation constraints are satisfied if and only if

$$
\chi \leq \phi \leq 1
$$

This condition ensures that bilateral trades are completely voluntary. Given these requirements, it is now straightforward to formally define a stationary equilibrium in the absence of perfect public information.

Definition 3 A stationary monetary equilibrium for the economy described above is an array $\left\{J^{0}, J^{1}, J^{d}, V^{0}, V^{1}, W^{0}, W^{1}, \phi, y, \alpha, m^{1}, m^{2}, m^{3}\right\}$ satisfying $m^{1}=1, m^{2}=m^{3}=\lambda$, 
$\alpha=1$, (1), (2), (3), (4), (5), (6), (7), (11), and (13). In addition, $J^{d}$ is the value associated with a banker's best deviation strategy when each banker is required to deposit with the clearinghouse the amount $\phi$, contingent on the creation of a note.

In the absence of perfect public information, it is necessary to add the value associated with a banker's best deviation strategy to the equilibrium definition. As previously mentioned, the value associated with a banker's best deviation strategy depends on the amount of good $x$ that each banker is required to deposit with the clearinghouse every time he has an opportunity to issue a note.

\subsection{Existence}

Now I formally show the existence of a stationary monetary equilibrium. In particular, I characterize the set of prices that can be supported as an equilibrium value of privately issued notes.

Proposition 4 Provided that $\chi<\beta$, there exists $\bar{\phi} \in(0,1)$ such that any value in the interval given by

$$
\chi \leq \phi \leq \bar{\phi}
$$

can be supported as an equilibrium value of notes in a stationary monetary equilibrium. In this equilibrium, the end-of-period excess reserves are $(1-\lambda) \phi$ at each date.

Proof. To show the existence of an upper bound $\bar{\phi}$, I construct candidates $\left\{\bar{\phi}_{s}\right\}_{s=0}^{\infty}$ and $\left\{J_{s}^{d}\right\}_{s=0}^{\infty}$ as follows. Define

$$
J_{0}^{d}=\frac{1-(1-\lambda)^{2} \beta}{1-(1-\lambda) \beta} .
$$

If (11) holds with equality, then the value of notes is given by

$$
\bar{\phi}_{0}=\frac{1-\beta(1-\lambda)-(1-\beta) J_{0}^{d}}{1-\beta(1-\lambda)} .
$$

Given this choice for the value of notes, there exists a value associated with a best deviation strategy, $J_{1}^{d}$. It follows that $J_{1}^{d} \leq J_{0}^{d}$. Given $J_{1}^{d}$, I can define $\bar{\phi}_{1}$ as follows:

$$
\bar{\phi}_{1}=\frac{1-\beta(1-\lambda)-(1-\beta) J_{1}^{d}}{1-\beta(1-\lambda)} .
$$


Note that $\bar{\phi}_{1} \geq \bar{\phi}_{0}$. Following the same steps as those described above, I can define an increasing sequence $\left\{\bar{\phi}_{s}\right\}_{s=0}^{\infty}$ and a decreasing sequence $\left\{J_{s}^{d}\right\}_{s=0}^{\infty}$. Because $\left\{J_{s}^{d}\right\}_{s=0}^{\infty}$ is bounded, it converges to a unique limit $J^{d}>1$. Because $\left\{\bar{\phi}_{s}\right\}_{s=0}^{\infty}$ is bounded, it converges to a unique limit $\bar{\phi}<1$.

To see that the end-of-period excess reserves are given by $(1-\lambda) \phi$, note that all merchants who have acquired a note are able to convert it into $\phi$ unit of good $x$ in the settlement stage. Note also that there is no reason for them to delay the redemption of a note. Because $m^{1}=1$ in a stationary equilibrium and note holdings are constrained to the set $\{0,1\}$, the total volume of reserves at the end of the first stage must be given by $\phi$. Because $m^{2}=\lambda$, the total volume of reserves decreases by the amount $\lambda \phi$ in the settlement stage. This means that the end-of-period volume of excess reserves is $(1-\lambda) \phi$.

The description of an equilibrium allocation is the same as before. In a stationary equilibrium, each banker consumes $1-\phi$ unit of good $x$ when he has an opportunity to issue a note, each consumer consumes $\omega^{-1} v(\phi)$ units of good $y$ when he has an opportunity to trade with a merchant and produces one unit of good $x$ when he acquires a note, and each merchant produces $\omega^{-1} v(\phi)$ units of good $y$ and consumes $\phi$ unit of good $x$ when he has an opportunity to trade with a consumer.

Because $J^{d}>1$, we have $\bar{\phi}<1$. This means that the set of implementable equilibrium allocations is smaller in the case of imperfect public information. This means that a sound banking system of the kind described in this section costs something for nonbanks. The equilibrium value $\phi \in[\chi, \bar{\phi}]$ is determined in such a way that each banker obtains a flow of income derived from his note-issuing privileges that is sufficient to induce him to hold reserves (deposited with the clearinghouse for safekeeping) to fully secure his demandable liabilities. This ensures that each banker is willing to adopt a very safe form of banking (as determined by the clearinghouse reserve requirements) so that traders do not have to worry about potential losses on their note holdings due to bank failures. In other words, to ensure the stability of the banking system and the safety of bank notes as a payment instrument, it is necessary to impose a maximum rate of return offered on notes to induce each banker 
to truthfully report the creation of notes and deposit the appropriate amount of reserves to secure them. In other words, a safe banking system costs something for nonbanks.

\section{A BANK COALITION}

The problem with the arrangement described above is that the banking system as a whole holds excess reserves at the end of each date. It would be desirable to find an alternative institutional arrangement that allows the members of the banking system to consume these excess reserves without compromising the stability of the banking system (i.e., the fact that there is no bank failure on the equilibrium path). One way to achieve this goal is to implement a joint-liability arrangement as follows. Suppose now that, at the beginning of date zero, the members of the clearinghouse association agree to issue notes that are joint obligations of its members. Each banker continues to issue notes that identify him as a debtor, but the clearinghouse publicly announces that any note issued by a banker who is a member of the coalition will be honored, according to the joint capacity of all members.

At date zero, each banker is initially matched with a consumer without a note. This means that each banker has an opportunity to issue a note to the consumer with whom he is initially matched. I continue to restrict attention to the same invariant distributions as those described above. This means that only a fraction $\lambda$ of all outstanding notes will be retired in the settlement stage. Note also that, after date zero, the total volume of reserves of the coalition will increase by $\lambda \phi$ in the first stage due to the creation of notes. In the settlement stage, the total volume of reserves of the coalition will decrease by the same amount, i.e., the total volume of redemptions will be given by $\lambda \phi$. This means that the coalition has enough reserves to pay the full face value of each note that is presented for redemption at date one and at any other subsequent date. Thus, the solvency of the coalition as a whole is ensured.

Suppose the clearinghouse announces that each banker is now required to deposit the amount $\lambda \phi$ for each note issued at date zero. From date $t \geq 1$ on, it requires member banks to deposit the usual amount $\phi$ for each note issued. Because only a fraction $\lambda$ of 
all outstanding notes will be retired in the settlement stage, this means that each note holder continues to receive the face value $\phi \in[\chi, \bar{\phi}]$ for each note he or she presents for redemption. As previously mentioned, the value associated with a banker's best deviation strategy depends on the amount of good $x$ that each banker is required to set aside every time he has an opportunity to issue a note. Under a joint-liability arrangement, the clearinghouse requires each banker to deposit a smaller amount at date zero. This means that the value associated with a best deviation strategy at date zero is at most the same as the stationary value $J^{d}$. Thus, the banker's truth-telling constraint is clearly satisfied at date zero. This means that, under a joint-liability arrangement, each banker is able to increase his consumption at date zero while keeping the consumption of other agents unchanged.

Note that this kind of welfare-improving arrangement is only feasible because of the implementation of a joint-liability scheme (the agreement to form a bank coalition and engage in a risk-sharing arrangement). The fact that a note issued by a member of the bank coalition is a joint obligation of all members allows the banking system to perform the ex post transfer of reserves from liquid bankers (those who have not been called for redemption) to illiquid bankers (those who have been called for redemption and have to pay an amount, $\phi$, that is greater than the amount of reserves each one of them has deposited, $\lambda \phi)$. This implies that it will no longer be necessary to have excess reserves. Indeed, at the end of date zero, there will be no excess reserves in the system. This means that each banker is able to engage in fractional reserve banking without compromising the stability of the banking system. This can only be accomplished in the presence of a bank coalition of the kind described above. Thus, I have just proved the following proposition.

Proposition 5 Suppose the members of the clearinghouse association agree to issue notes that are joint obligations of its members. Then, it is possible to construct an equilibrium in which the value of notes is given by $\phi \in[\chi, \bar{\phi}]$ at each date and each banker consumes the amount $1-\lambda \phi$ at date zero and consumes the amount $1-\phi$ when he has an opportunity to issue a note at any other date. In this equilibrium, the production of good y is given by $\omega^{-1} v(\phi)$ in each meeting. 
It is clear that the allocation obtained under a joint-liability arrangement Pareto dominates the allocation obtained in the absence of a risk-sharing arrangement. In particular, note that each banker is strictly better off by agreeing to issue joint liabilities. This means that he strictly prefers to form a coalition of this type.

The gain to each banker from joining the coalition is temporary because of the assumption that there is only one asset available to each banker that pays off one unit of good $x$ for each unit invested. Each banker would be able to obtain a permanent gain (an extra consumption amount at each date) by forming a bank coalition if an asset with a higher rate of return was available. For instance, Sanches (2013) introduces a long-term asset (an asset that requires

good $x$ as an input today but that pays off a higher return in the following date) into the environment and shows that the gain to each banker is indeed permanent.

The important result of this section is to show that a joint-liability scheme is an effective arrangement that permits the members of the clearinghouse to implement a more efficient management of bank reserves, allowing each banker to temporarily increase his consumption. Thus, there exists an institutional arrangement that permits member banks to engage in fractional reserve banking and that preserves the safety of bank liabilities as a means of payment.

\section{AGGREGATE SHOCK}

Suppose now that, at date zero, there is an aggregate shock that affects the return to the storage technology only at date zero. In particular, assume that, with probability $\pi \in(0,1)$, the return to each unit invested in the storage technology at date zero is $\theta<1$ and, with probability $1-\pi$, the return equals one. The shock is realized in the third subperiod. From date one onward, there is no other shock, and this is common knowledge. This means that any amount of good $x$ that is invested in the storage technology at date one or at any subsequent date will return one unit of the same good at the moment it is liquidated.

This shock means that, with probability $\pi$, the aggregate value of the assets of the banking sector will temporarily fall at date zero. This means that the technology backing 
the liabilities of the banking system at date zero is now risky. This is equivalent to saying that the assets of the banking sector are risky and that an event can lead to a temporary fall in the aggregate value of these assets. Because the realization of the shock happens only in the settlement stage, people have to trade in stages 1 and 2 without knowing the actual aggregate state. Thus, the goal of this section is to investigate whether the private payment system contracts in response to the aggregate shock (i.e., whether the safety of bank liabilities as a means of payment is preserved in the presence of a bank coalition).

I continue to assume that people cannot observe the creation of bank notes and that the members of the clearinghouse engage in a joint-liability arrangement of the kind I have described in the previous section. In the presence of an aggregate shock at date zero, the relevant measure to determine the solvency of each banker who is called for redemption at date zero is the ratio of the value of all reserves of the coalition to the value of all notes that are presented for redemption at date zero. Formally, this measure is given by

$$
\frac{\theta \phi_{0}}{\lambda \phi_{0}}=\frac{\theta}{\lambda}
$$

If this ratio is greater than or equal to one, then the coalition is solvent, in which case each member who is called for redemption will be able to pay the full face value of his note. If this ratio is less than one, then the coalition is insolvent, in which case each member who is called for redemption will be unable to redeem his note at par value.

First, suppose that $\lambda \leq \theta$. If the adverse state is realized, then the value of all reserves of the coalition is sufficient to guarantee the conversion of all notes, at the par value $\phi \in[\chi, \bar{\phi}]$, that are presented for redemption at date zero. Because the clearinghouse has enough reserves to perform the reallocation of reserves from bankers who have not been called for redemption to bankers who need to pay out an amount that is greater than their individual reserve balances, the equilibrium value $\phi$ is feasible at date zero in case $\lambda \leq \theta$. Thus, it is possible to implement the same equilibrium value of privately issued notes as the stationary value obtained when there is no aggregate shock.

It remains to verify whether the members of the clearinghouse will be able to fulfill their promises after date zero, given that the reserves of the bankers who have not been called for 
redemption at date zero have been used to meet the obligations of the coalition. Note that the total volume of reserves of the coalition will increase by $\lambda \phi$ in the first stage owing to the creation of notes. In the settlement stage, the total volume of reserves of the coalition will decrease by the same amount, i.e., the total volume of redemptions is given by $\lambda \phi$. This means that the coalition has enough reserves to pay the full face value of each note that is presented for redemption in the settlement stage at date one and at any other subsequent date. Now I summarize these findings in the following proposition.

Proposition 6 Suppose the members of the clearinghouse agree to implement a jointliability arrangement. If $\lambda \leq \theta$, then it is possible to construct an equilibrium in which the value of notes is given by $\phi \in[\chi, \bar{\phi}]$ and each banker consumes the amount $1-\theta^{-1} \lambda \phi$ at date zero and consumes at least the amount $1-\phi$ when he has an opportunity to issue a note at any other date. In this equilibrium, the production of good $y$ is given by $\omega^{-1} v(\phi)$ in each meeting.

Note that the clearinghouse association has provided full insurance to the nonbank public, i.e., all bank notes are redeemed at the par value $\phi \in[\chi, \bar{\phi}]$ and each consumer obtains $\omega^{-1} v(\phi)$ units of good $y$ when he has an opportunity to trade with a merchant. Thus, the bank coalition described above is an effective arrangement that ensures the ex post transfer of reserves from banks that are liquid to banks that find themselves illiquid so that the safety of bank notes as a means of payment is completely preserved. Note that the members of the bank coalition bear the losses. In the absence of an aggregate shock, I have shown that each banker is able to temporarily increase his consumption by engaging in a jointliability arrangement because it allows him to economize on reserves at date zero. In the presence of an aggregate shock, each banker continues to be able to temporarily increase his consumption by forming a coalition and agreeing to issue joint liabilities. However, such an increase is now smaller because each banker is willing to fully absorb the effects of the shock. In particular, the consumption of each banker at date zero is now given by $1-\theta^{-1} \lambda \phi<1-\lambda \phi$ because the smallest required deposit amount that the clearinghouse can implement is now given by $\theta^{-1} \lambda \phi>\lambda \phi$. Thus, I can interpret the kind of bank coalition described above as 
an effective arrangement that creates a capital buffer (the extra consumption amount) to absorb the effects of a shock to the value of banking assets.

Now suppose that $\lambda>\theta$. If the adverse state is realized, then the value of all reserves of the coalition is lower than the value of all notes that are presented for redemption at date zero when each banker sets aside only the face value of his notes. This means that the coalition is insolvent. Thus, the difference from the previous case is that now each note holder will receive $\lambda^{-1} \theta \phi<\phi$ (i.e., only a fraction $\lambda^{-1} \theta$ of the face value of his note) from the members of the bank coalition if the adverse state is realized. Thus, the promised payment is different from the actual payment in case the adverse state is realized. This kind of response by the members of the clearinghouse can be interpreted as a partial suspension of convertibility of bank liabilities, an expedient to which banks resorted frequently to preserve bank capital. It is important to emphasize that the partial suspension is completely anticipated by each trader.

From an economic perspective, the possibility of individual losses allows the clearinghouse to implement state-contingent payoffs in an environment in which contracts are initially designed to be noncontingent. In the favorable state of nature, the return to storage equals one, in which case the promised payment to each note holder equals the actual payment, namely, the face value $\phi$. In the adverse state of nature, the return to storage is less than one, in which case the actual payment is less than the promised payment because of bankruptcy protection.

In each bilateral meeting between a consumer and a merchant, the amount of good $y$ produced is now given by

$$
y_{0}=\omega^{-1}\left[(1-\pi) v(\phi)+\pi v\left(\lambda^{-1} \theta \phi\right)\right]
$$

Note that consumers and merchants fully anticipate the smaller actual payment in case the adverse state is realized. Because each merchant perfectly anticipates the actual payments in each state, he is willing to accept a banker's note (i.e., choose $\alpha=1$ ) provided that $y_{0}$ is given by (15) and the banker's truth-telling constraint holds.

I also have to describe what happens in a meeting in which a consumer who has acquired 
a banker's note at date zero uses such a note to trade with a merchant after date zero. Any note issued at date zero that was not presented for redemption at that date can be retired at par value at a subsequent date because, as I have previously mentioned, the members of the bank coalition are able to deposit enough reserves at the beginning of each date (first stage) to retire all notes that are presented for redemption at the end of each date (settlement stage) in the absence of any shock. The consumer who pays for his purchases with such a note at any subsequent date will get

$$
y_{t}=\omega^{-1} v(\phi)
$$

units of good $y$ from a merchant, which is the same as the stationary amount obtained in the absence of an aggregate shock. Thus, the expected discounted utility for each consumer at the beginning of date zero is given by

$$
-\gamma+\lambda\left[u\left(y_{0}\right)+\beta V^{0}\right]+(1-\lambda) \beta V^{1},
$$

where the amount of good $y$ produced at date zero is given by (15) and the values $V^{0}$ and $V^{1}$ are given by (1) and (2), respectively.

Proposition 7 Suppose the members of the clearinghouse agree to implement a jointliability arrangement. If $\lambda>\theta$, then it is possible to construct an equilibrium in which the value of notes is given by $\phi \in\left[\chi^{\prime}, \bar{\phi}\right]$ and each banker consumes at least $1-\phi$ when he has an opportunity to issue a note, where $\chi<\chi^{\prime}<\frac{\lambda}{\theta} \chi$. In this equilibrium, the production of good $y$ is given by (15) in each meeting at date zero and is given by $\omega^{-1} v(\phi)$ in each meeting after date zero.

Proof. Because traders fully anticipate the actual payments contingent on the realization of the aggregate shock at date zero, the consumer's participation constraint at that date is given by

$$
-\gamma+\lambda u\left(\omega^{-1}\left[(1-\pi) v(\phi)+\pi v\left(\lambda^{-1} \theta \phi\right)\right]\right)+\beta(1-\lambda)\left(V^{1}-V^{0}\right) \geq 0 .
$$

Rearranging this expression, I obtain the following inequality:

$$
(1-\pi) v(\phi)+\pi v\left(\lambda^{-1} \theta \phi\right) \geq \omega u^{-1}\left(\frac{(1-\beta+\beta \lambda) \gamma}{\lambda}\right)
$$


Because

$$
v(\phi)>v\left((1-\pi) \phi+\pi \lambda^{-1} \theta \phi\right) \geq(1-\pi) v(\phi)+\pi v\left(\lambda^{-1} \theta \phi\right),
$$

it follows that there exists a value $\chi^{\prime}>\chi$ such that (16) holds if and only if $\phi \geq \chi^{\prime}$.

In the case of a relatively large shock, note holders bear some losses, together with bankers. Note that bankers limit their losses to the extra consumption amount that each one of them obtains by forming a bank coalition. The partial suspension of convertibility occurs because there exists a limit to the amount of losses that each banker is willing to bear, which is determined by the banker's truth-telling constraint. As I have shown, the banker's truthtelling constraint ensures that each banker is willing to deposit the appropriate amount of reserves with the clearinghouse. In the adverse state of nature, the value of these reserves is insufficient to pay the full face value of notes. Because it is costly to induce bankers to hold more reserves, it is necessary to adopt a partial suspension of convertibility to preserve a minimum level of bank capital.

\section{CONCLUSION}

I have characterized the welfare properties of a specific type of bank coalition: a jointliability arrangement. As opposed to markets, this form of bank organization involves the monitoring and supervision of the activities of member banks so that it is possible to effectively perform the transfer of reserves from liquid banks to illiquid banks. In particular, I have shown that the implementation of a joint-liability arrangement allows member banks to economize on reserves and build a capital buffer that permits them to fully absorb the effects of an aggregate shock, at least in the case of a shock that is not too big. The precise meaning of a real shock that is not too big, in the context of my analysis, is a shock such that the value of the reserves of all member banks in the adverse state of the world is sufficient to satisfy the demands for redemption by the public so that each bank liability holder receives the full face value. As a result, the safety of bank liabilities as a means of payment is completely preserved so that trading activity is not disrupted.

If the external shock is relatively large, then the bank coalition will not be able to prevent 
a disruption in trading activity even though it can substantially mitigate the effects of such a shock by resorting to partial suspension of convertibility. In this case, nonbanks also bear some losses, which is a required outcome to preserve a minimum level of bank capital. For this reason, I refer to this event as a banking crisis. Despite the inability of a private bank coalition to completely prevent the effects of sufficiently large shocks, I can certainly conclude that a joint-liability arrangement is an effective form of organization for members of the banking sector in the absence of any government agency designed to supervise and intervene in banking activities. This arrangement is especially valuable to the members of society when banks have limited opportunities to expand their operations due to geographic and other legal restrictions.

\section{REFERENCES}

[1] F. Allen, E. Carletti, D. Gale. "Money, financial stability, and efficiency," Journal of Economic Theory (forthcoming).

[2] D. Andolfatto, E. Nosal. "Money, intermediation, and banking," Journal of Monetary Economics 56 (2009), pp. 289-294.

[3] L. Araujo, R. Minetti. "On the essentiality of banks," International Economic Review 52 (2011), pp. 679-691.

[4] C. Azariadis, J. Bullard, B. Smith. "Private and public circulating liabilities," Journal of Economic Theory 99 (2001), pp. 59-116.

[5] S. Battacharya, D. Gale. "Preference Shocks, Liquidity and Central Bank Policy," in W. Barnett and K. Singleton, eds., New Approaches to Monetary Economics. New York: Cambridge University Press (1987), pp. 69-88.

[6] A. Berentsen. "On the private provision of fiat currency," European Economic Review 50 (2006), pp. 1683-1698.

[7] R. Cavalcanti, A. Erosa, T. Temzelides. "Private money and reserve management in a 
random-matching model," Journal of Political Economy 107 (1999), pp. 929-945.

[8] R. Cavalcanti, N. Wallace. "A model of private bank-note issue," Review of Economic Dynamics 2 (1999), pp. 104-136.

[9] A. Deviatov, N. Wallace. "A model in which monetary policy is about money," Journal of Monetary Economics 56 (2009), pp. 283-288.

[10] D. Diamond, P. Dybvig. "Bank runs, deposit insurance, and liquidity," Journal of Political Economy 91 (1983), pp. 401-419.

[11] M. Friedman, A. Schwartz. A Monetary History of the United States, 1867-1960, Princeton University Press, 1963.

[12] G. Gorton. "Private clearinghouses and the origins of central banking," Business Review, Federal Reserve Bank of Philadelphia, January-February (1984), pp. 3-12.

[13] G. Gorton. "Clearinghouses and the origins of central banking in the U.S." Journal of Economic History 45 (1985), pp. 277-283.

[14] G. Gorton, L. Huang. "Bank panics and the endogeneity of central banking," Journal of Monetary Economics 53 (2006), pp. 1613-1629.

[15] G. Gorton, D. Mullineaux. "The joint production of confidence: endogenous regulation and the 19th century commercial bank clearinghouse," Journal of Money, Credit and Banking 19 (1987), pp. 457-468.

[16] C. Gu, F. Mattesini, C. Monnet, R. Wright. "Banking: a new monetarist approach," Review of Economic Studies, forthcoming.

[17] P. He, L. Huang, R. Wright. "Money, banking, and monetary policy," Journal of Monetary Economics 55 (2008), pp. 1013-1024.

[18] S. Huangfu, H. Sun. "Private money and bank runs," Canadian Journal of Economics 44 (2011), pp. 859-879. 
[19] C. Kahn, W. Roberds. "Demandable debts as a means of payment: banknotes versus checks," Journal of Money, Credit and Banking 31 (1999), pp. 500-525.

[20] T. Koeppl, C. Monnet, T. Temzelides. "A dynamic model of settlement," Journal of Economic Theory 142 (2008), pp. 233-246.

[21] Y. Leitner. "Financial networks: contagion, commitment, and private sector bailouts," Journal of Finance 60 (2005), pp. 2925-2953.

[22] Y. Li. "A search model of money and circulating private debt with applications to monetary policy," International Economic Review 42 (2001), pp. 925-946.

[23] Y. Li. "Banks, private money, and government regulation," Journal of Monetary Economics 53 (2006), pp. 2067-2083.

[24] A. Martin, S. Schreft. "Currency competition: a partial vindication of Hayek," Journal of Monetary Economics 53 (2006), pp. 2085-2111.

[25] J. McAndrews, W. Roberds. "Banks, payments, and coordination," Journal of Financial Intermediation 4 (1995), pp. 305-327.

[26] D. Mills. "A model in which outside and inside money are essential," Macroeconomic Dynamics 11 (2007), pp. 219-236.

[27] J. Moen, E. Tallman. "The bank panic of 1907: the role of trust companies," Journal of Economic History 52 (1992), pp. 611-630.

[28] J. Moen, E. Tallman. "Clearinghouse membership and deposit contraction during the panic of 1907," Journal of Economic History 60 (2000), pp. 145-163.

[29] A. Rolnick, B. Smith, W. Weber. "The Suffolk bank and the panic of 1837," Federal Reserve Bank of Minneapolis Quarterly Review 24 (2000), pp. 3-13.

[30] D. Sanches. "On the welfare properties of fractional reserve banking," Working Paper No. 13-32, Federal Reserve Bank of Philadelphia (2013). 
[31] S. Shi. "Money and prices: a model of search and bargaining," Journal of Economic Theory 67 (1995), pp. 467-496.

[32] D. Skeie. "Banking with nominal deposits and inside money," Journal of Financial Intermediation 17 (2008), pp. 562-584.

[33] B. Smith, W. Weber. "Private money creation and the Suffolk banking system," Journal of Money, Credit and Banking 31 (1999), pp. 624-659.

[34] A. Trejos, R. Wright. "Search, bargaining, money, and prices," Journal of Political Economy 103 (1995), pp. 118-141.

[35] S. Williamson. "Private money," Journal of Money, Credit and Banking 31 (1999), pp. 469491. 


\section{Figure 1: Sequence of Events within a Period}

\begin{tabular}{|c|c|c|c|}
\hline \multicolumn{2}{|c|}{ Stage 1} & Stage 2 & Stage 3 \\
\hline $\begin{array}{l}\text { Bilateral } \\
\text { meetings } \\
\text { between banker } \\
\text { and consumer }\end{array}$ & $\begin{array}{l}\text { All bankers } \\
\text { move to the } \\
\text { centralized } \\
\text { location } \\
\text { until the end } \\
\text { of the } \\
\text { period }\end{array}$ & $\begin{array}{l}\text { Bilateral } \\
\text { meetings } \\
\text { between } \\
\text { consumer and } \\
\text { merchant }\end{array}$ & $\begin{array}{l}\text { All } \\
\text { merchants } \\
\text { move to the } \\
\text { centralized } \\
\text { location }\end{array}$ \\
\hline
\end{tabular}




\section{Figure 2: Creation and Redemption of Bank Notes with Perfect Public Information}

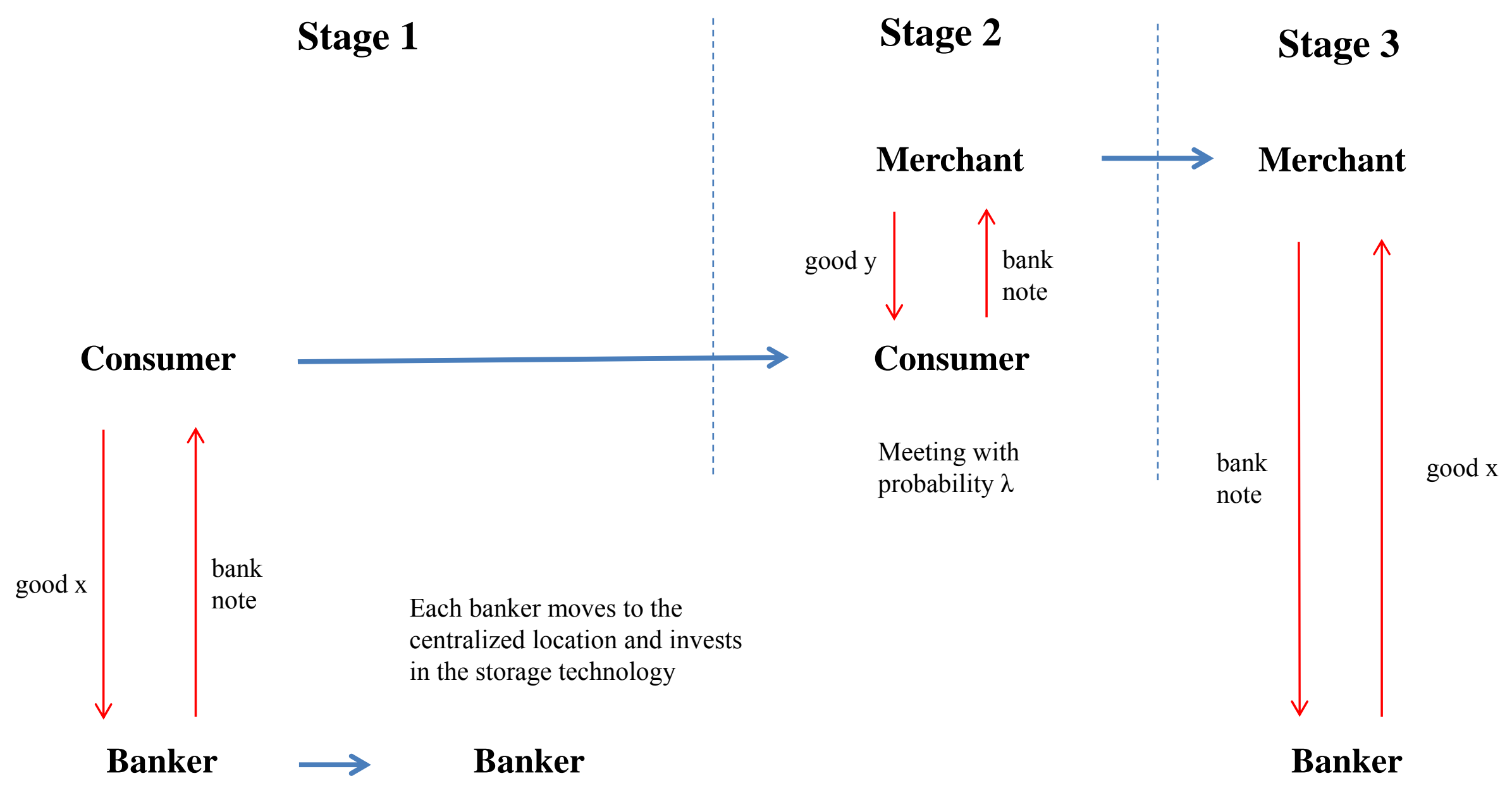




\section{Figure 3: Creation and Redemption of Bank Notes with Imperfect Public Information}
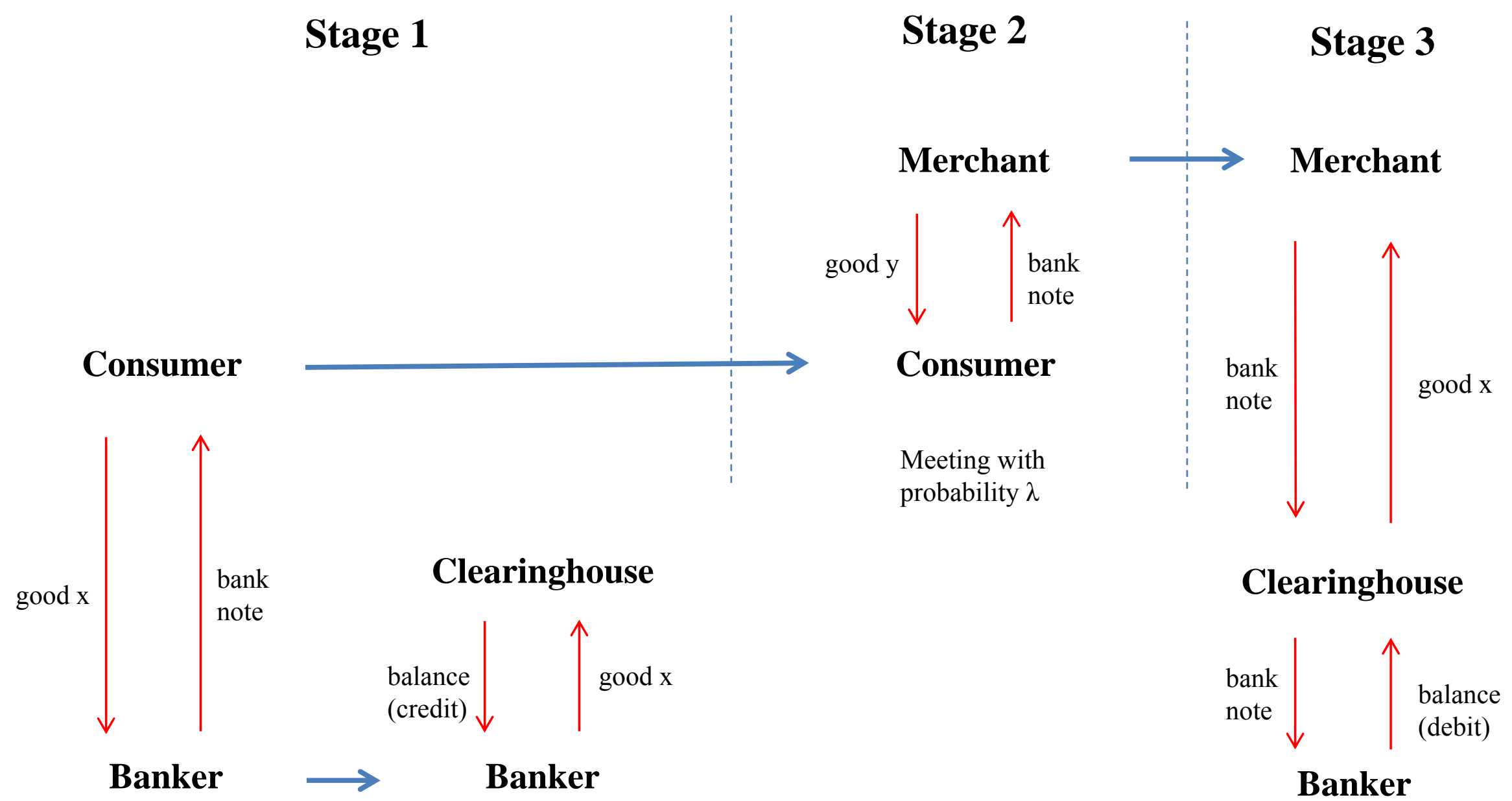